\title{
The Effect of Mesoporous Carbon Nitride Modification by Titanium Oxide Nanoparticles on Photocatalytic Degradation of 1,3-Dinitrobenzene
}

DOI: $10.15255 /$ KUI.2014.025 KUI-33/2015

Original scientific paper

Received August 5, 2014 Accepted November 15, 2014

\author{
S. E. Moradi* \\ Young Researchers and Elite Club, \\ Islamic Azad University-Sari Branch 39715-194, Iran
}

\begin{abstract}
A Abstract
In the present work, well ordered, mesoporous carbon nitride $(\mathrm{MCN})$ sorbent with uniform mesoporous wall, high surface area and pore volume has been fabricated using the simple polymerization reaction between ethylene diamine and carbon tetrachloride in mesoporous silica media, and then modified by $\mathrm{TiO}_{2}$ nanoparticles (Ti-MCN). The structural order and textural properties of the nanoporous materials were studied by XRD, elemental analysis, and nitrogen adsorption-desorption experiments. Photodegradation experiments for 1,3-dinitrobenzene were conducted in batch mode, the Ti-MCN catalysts were found to be more active compared to the free $\mathrm{TiO}_{2}$ nanoparticles for 1,3-dinitrobenzene degradation.
\end{abstract}

\| Keywords

1,3-dinitrobenzene, mesoporous carbon nitride, degradation, titanium oxide

\section{Introduction}

Soil polluted through poisonous or hazardous organic pollutants is an ecological concern. Hydrophobic organic compounds have attracted intensive attention because they are powerfully adsorbed into soil and known as toxic, persistent and carcinogenic pollutants ${ }^{1,2}$ in ecosystem. These compounds can reach the environment as a result of fossil fuel burning, coke burning, metal processing facilities, hydrocarbon production, and so on..$^{3,4}$

Several treatment methods for the removal of organic pollutants from aqueous solutions have been reported, mainly electrochemical treatments, evaporation, solvent extraction, reverse osmosis, chemical precipitation, membrane filtration and adsorption. ${ }^{5}$ Most of these methods involve high capital cost and are not suitable for small-scale industries. The removal of toxic pollutants from water is a problem, particularly when they are present in low concentrations. Several studies have focused on the fate and transport of these pollutants, and the application of remedial technologies to manage them. ${ }^{6,7}$ The most common adsorbent material are carbon-based adsorbents, which have a huge specific surface area, plentiful micro and macro pores, and a high adsorption capacity. These adsorbents are economically favourable because they can be made from various low-cost materials that have high carbonaceous content including wood, coal, petroleum coke, sawdust and coconut shell. ${ }^{8}$ On the other hand, photocatalysis on $\mathrm{TiO}_{2}$ surfaces is of great importance today with the intention to serve as a solution for numerous environmental issues like wastewater treatment and remediation, hazard-

* Seyyed Ershad Moradi, PhD

e-mail: ermoradi@hotmail.com ous waste control and air cleansing. Moreover, $\mathrm{TiO}_{2}$ is low-cost whereat titanium is the world's seventh most plentiful metal and ninth most plentiful element. ${ }^{9,10} \mathrm{TiO}_{2}$ has found uses as white pigment and UV absorber in food and paint industries and cosmetics. ${ }^{11}$ Though, the major drawback in $\mathrm{TiO}_{2}$ photocatalysis is low efficiency due to the high rate of recombination of electrons and holes upon photoactivation. ${ }^{12}$ Due to its wide bandgap energy, eg., of $3.0-3.2 \mathrm{eV}$, it can only be activated by UV light, which coincidentally accounts only $3-4 \%$ of sunlight spectrum. ${ }^{13}$ To have an improved photocatalytic efficiency, composite photocatalysts were designed by loading $\mathrm{TiO}_{2}$ on certain support substrates with large surface areas. ${ }^{14}$

Recently, Vinu et al. ${ }^{15}$ reported the synthesis of mesoporous $\mathrm{CN}$ materials based on pyridine- and benzene-ring building blocks by using mesoporous silica as a hard template and ethylenediamine (EDA) and carbon tetrachloride (CTC) as precursors.

Scientists recently used carbon-based materials as catalyst supports associated with photo- or electro-catalysis, the good electron conducting character of carbon supports may have some helpful influence in increasing catalytic activities. However, there are only limited publications concerning this effect.

In this work, the influence of the $\mathrm{TiO}_{2}$ loading on mesoporous carbon nitride support were systematically studied in the photodegradation of 1,3-dinitrobenzene (NB). For this purpose, the $\mathrm{MCN}$ were modified by $\mathrm{TiO}_{2}$ nanoparticle. The activity of this catalyst was compared with pure $\mathrm{TiO}_{2}$ in the photodegradation of 1,3-dinitrobenzene in aqueous solution. The effects of contact time and initial solution concentration on 1,3-dinitrobenzene degradation has been investigated. 


\section{Experimental}

\subsection{Materials}

The reactants used in this study were tetraethyl orthosilicate (TEOS), cetyltrimethylammonium bromide (CTAB), sodium hydroxide $(\mathrm{NaOH})$, sodium fluoride $(\mathrm{NaF})$, sucrose, sulfuric acid $\left(\mathrm{H}_{2} \mathrm{SO}_{4}\right)$, EDA (ethylene diamine), CTC (carbon tetrachloride), acetic anhydride, Ti-isopropoxide and 1,3-dinitrobenzene. All the chemicals were analytical grade and purchased from Merck (Darmstadt, Germany).

\subsection{Experimental Procedure}

\subsubsection{Synthesis of mesoporous silica (MCM-48)}

MCM-48 was prepared according to the synthesis procedure described by Yaofeng Shao. ${ }^{16}$ In a representative synthesis, the MCM-48 molecular sieves were prepared as follows: $10 \mathrm{ml}$ of TEOS was mixed with $50 \mathrm{ml}$ of deionized water, and the mixture was vigorously stirred for $40 \mathrm{~min}$ at $308 \mathrm{~K}$, then $0.9 \mathrm{~g}$ of $\mathrm{NaOH}$ was added into mixture, and at the same time $0.19 \mathrm{~g}$ of $\mathrm{NaF}$ was added into the mixture. After the $\mathrm{NaF}$ was added completely, the required content of sucrose, respectively, was added. After another $60 \mathrm{~min}$ of vigorous stirring, $10.61 \mathrm{~g}$ of CTAB was added to the mixture, and stirring continued for $60 \mathrm{~min}$. The mixture was heated for $24 \mathrm{~h}$ at $393 \mathrm{~K}$ in an autoclave under static conditions, and the resulting product was filtered, washed with distilled water, and dried at $373 \mathrm{~K}$. The as-synthesized samples were then calcined in air for $4 \mathrm{~h}$ at $823 \mathrm{~K}$, increasing the temperature to $823 \mathrm{~K}$ at $1{ }^{\circ} \mathrm{C} \mathrm{min}^{-1}$ of the heating rate.

\subsubsection{Synthesis of mesoporous carbon nitride (MCN)}

Mesoporous carbon nitride materials were prepared by using mesoporous silica MCM-48 as template. In a typical synthesis, $0.5 \mathrm{~g}$ of calcined MCM-48 was added to a mixture of EDA $(1.35 \mathrm{~g})$ and CTC $(3 \mathrm{~g})$. The resultant mixture was refluxed and stirred at $363 \mathrm{~K}$ for $6 \mathrm{~h}$. Then, the obtained dark brown solid mixture was placed in a drying oven for $12 \mathrm{~h}$, and ground into fine powder. The template-carbon nitride polymer composites were then heat-treated in a nitrogen flow of $50 \mathrm{ml}$ per min at $873 \mathrm{~K}$ with a heating rate of $3.0^{\circ} \mathrm{C} \mathrm{min}^{-1}$ and kept under these conditions for $5 \mathrm{~h}$ to carbonize the polymer. The mesoporous carbon nitride was recovered after dissolution of the silica framework in $5 \%$ hydrofluoric acid, by filtration, washed several times with ethanol, and dried at $373 \mathrm{~K}$.

\subsection{3. $\mathrm{TiO}_{2}$ loaded mesoporous carbon nitride photocatalyst}

In order to incorporate the $\mathrm{TiO}_{2}, 0.1 \mathrm{~g}$ mesoporous carbon nitride was mixed with $20 \mathrm{ml}$ isopropanol, stirred for several minutes. Then $0.105 \mathrm{ml}$ Ti-isopropoxide was added. The mixture was stirred overnight. Isopropanol was removed by centrifugation, and the material was further washed with acetone. The sample was air-dried at $80{ }^{\circ} \mathrm{C}$ overnight.

\subsection{Characterization}

The X-ray powder diffraction patterns were recorded on a Philips 1830 diffractometer using $\mathrm{Cu} \mathrm{K} \mathrm{K}_{\alpha}$ radiation. The diffractograms were recorded in the $2 \theta$ range of $0.8-10$ with a $2 \theta$ step size of $0.01^{\circ}$ and a step time of $1 \mathrm{~s}$.

The adsorption-desorption isotherm of the as-synthesized sample was measured at $77 \mathrm{~K}$ on micromeritics model ASAP 2010 sorptometer to determine an average pore diameter. Pore-size distribution was calculated by the Barrett-Joyner-Halenda (BJH) method while Brunauer-Emmett-Teller (BET) measured surface area of the sample.

\subsection{Photocatalytic activity measurements}

The photodegradation of 1,3-dinitrobenzene was done in order to calculate the photocatalytic activity of Ti-MCN photocatalyst. About $10 \mathrm{mg}$ of catalyst was mixed with $50 \mathrm{ml}$ of 1,3-dinitrobenzene aqueous solution (100 ppm) under magnetic stirring in dark for 30 minutes to reach the adsorption equilibrium of the 1,3-dinitrobenzene on the catalyst prior to irradiation. The photocatalytic activity of Ti-MCN was evaluated in the degradation of 1,3-dinitrobenzene aqueous solution under UV irradiation. The UV light source was a $125 \mathrm{~W} \mathrm{Hg} \operatorname{lamp}(\lambda=365 \mathrm{~nm})$. The average light intensity was $60 \mathrm{~mW} \mathrm{~cm}{ }^{-2}$. The distance between the light and the reaction tube was fixed at $12 \mathrm{~cm}$. The lamp was cooled with flowing water in a quartz cylindrical jacket around the lamp, and ambient temperature was maintained during the photocatalytic reaction because of good ventilation. An air diffuser was placed at the bottom of the reactor to uniformly disperse air into the solution and stirred with air at a flow rate of $0.2 \mathrm{~m}^{3} \mathrm{~h}^{-1}$. After irradiation and separation of the catalyst by centrifugation, the concentration of 1,3-dinitrobenzene was determined with a Perkin-Elmer Lambda 35 UV-Vis spectrophotometer. The 1,3-dinitrobenzene has an absorption maximum at $254 \mathrm{~nm}$. The concentration of 1,3-dinitrobenzene at diverse irradiation times was gained by converting absorbance of the solution to 1,3-dinitrobenzene concentration (Beer-Lambert's law, $A=\varepsilon b c$, where $A$ is absorbance, $\varepsilon$ molar absorption coefficient, $b$ pathlength, and $c$ concentration). A standard calibration curve (not shown here) was built by adjusting a different concentration of 1,3-dinitrobenzene solution and the absorption at $254 \mathrm{~nm}$. This calibration curve refers to the situation of the absence of by-products co-adsorption. A blank test was done in the solution without catalyst, where the concentration of the 1,3-dinitrobenzene indicates constancy.

\subsection{Photodegradation Kinetics}

Photocatalytic degradation of 1,3-dinitrobenzene yields carbon dioxide, nitrate and water. The zeros order kinetics is as shown in Eq. (1) 


$$
[\mathrm{NB}]_{\mathrm{i}}-[\mathrm{NB}]_{t}=k_{0} t
$$

The first order kinetics, is as shown in Eq. (2)

$$
\ln \frac{[N B]_{t}}{[N B]_{i}}=-k_{1} t
$$

where $[\mathrm{NB}]_{\mathrm{i}}$ indicate initial 1,3-dinitrobenzene concentration and $[\mathrm{NB}]_{\mathrm{t}}$ concentration at time $t$. If the reaction follows second order kinetics, it gives Eq. (3) which can also be rewritten in a non-linear form as shown in Eq. (4).

$$
\begin{aligned}
& \frac{1}{[\mathrm{NB}]_{t}}-\frac{1}{[\mathrm{NB}]_{\mathrm{i}}}=k_{2} t \\
& {[\mathrm{NB}]_{t}=\frac{[\mathrm{NB}]_{\mathrm{i}}}{[\mathrm{NB}]_{\mathrm{i}} k_{2} t+1}}
\end{aligned}
$$

\section{Result and discussion}

\subsection{Characterization}

\subsubsection{Adsorption-desorption analysis}

Besides powder XRD, nitrogen physisorption is the method of choice to gain knowledge about mesoporous materials. This method gives information on the specific surface area and the pore diameter. Calculating pore diameters of mesoporous materials using the $\mathrm{BJH}$ method is common. ${ }^{17}$ Former studies show that the application of the BJH theory gives appropriate qualitative results, which allow a direct comparison of relative changes between different mesoporous materials. $^{18-21}$

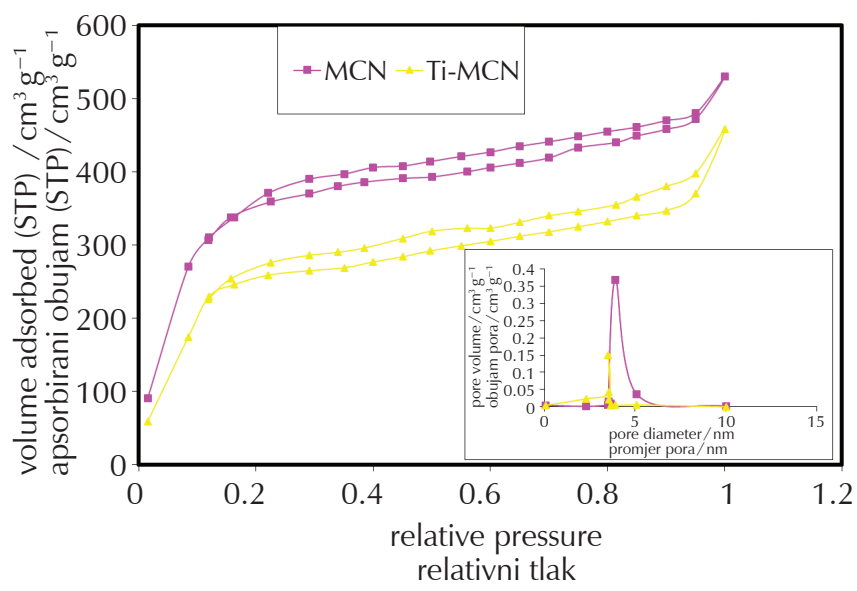

Fig. 1 - Adsorption-desorption isotherms of nitrogen at $77 \mathrm{~K}$ on $\mathrm{MCN}$ and Ti-MCN. The insert shows the BJH pore size distribution calculated from the desorption branch of the isotherm.

Slika 1 - Apsorpcijsko-desorpcijske izoterme dušika pri $77 \mathrm{~K}$ za MCN i Ti-MCN. Umetnuti graf pokazuje distribuciju veličine pora prema modelu BJH izračunatu iz desorpcijske grane izoterme.
Fig. 1 shows nitrogen adsorption and desorption isotherms measured at $77 \mathrm{~K}$ by using a Micromeritics ASAP 2010 automatic analyser. BET surface areas and the pore size determined by $\mathrm{BJH}$ method for the synthesized mesoporous sorbents ( $\mathrm{MCN}$ and Ti-MCN) were determined by the adsorption branches of the isotherms. All mesoporous materials yield a type IV isotherm. The isotherm of MCN is reversible and in good agreement with that previously reported. Table 1 summarizes the important physical properties of mesoporous sorbents. The surface areas of MCN and Ti-MCN samples were 1321 and $1280 \mathrm{~m}^{2} \mathrm{~g}^{-1}$, and their average pore size were 3.5 and $3.2 \mathrm{~nm}$, respectively. This result mainly depends on the pore size and shape for all nanostructured carbon materials.

Table 1 - Textural parameters of the MCN and Ti-MCN employed in this study

Tablica 1 - Karakteristični strukturni parametri MCN-a i Ti-MCN-a primijenjeni u ovoj studiji

\begin{tabular}{l|c|c|c}
\hline Adsorbent & $\begin{array}{c}\text { pore } \\
\text { diameter } / \mathrm{nm} \\
\text { promjer } \\
\text { pora/nm }\end{array}$ & $\begin{array}{c}\text { surface } \\
\text { area } / \mathrm{m}^{2} \mathrm{~g}^{-1} \\
\text { ploština } / \mathrm{m}^{2} \mathrm{~g}^{-1}\end{array}$ & $\begin{array}{c}\text { pore } \\
\text { volume } / \mathrm{cm}^{3} \mathrm{~g}^{-1} \\
\text { obujam } \\
\text { pora } / \mathrm{cm}^{3} \mathrm{~g}^{-1}\end{array}$ \\
\hline MCN & 3.5 & 1321 & 0.69 \\
Ti-MCN & 3.2 & 1280 & 0.72 \\
\hline
\end{tabular}

\subsection{2. $X R D$ analysis}

The XRD patterns of Ti-MCN and MCN showed (Fig. 2) three diffraction peaks that can be indexed to (110), (210), and (220) in the $2 \theta$ range from $0.8^{\circ}$ to $10^{\circ}$, representing well-ordered cubic 14,32 structure.

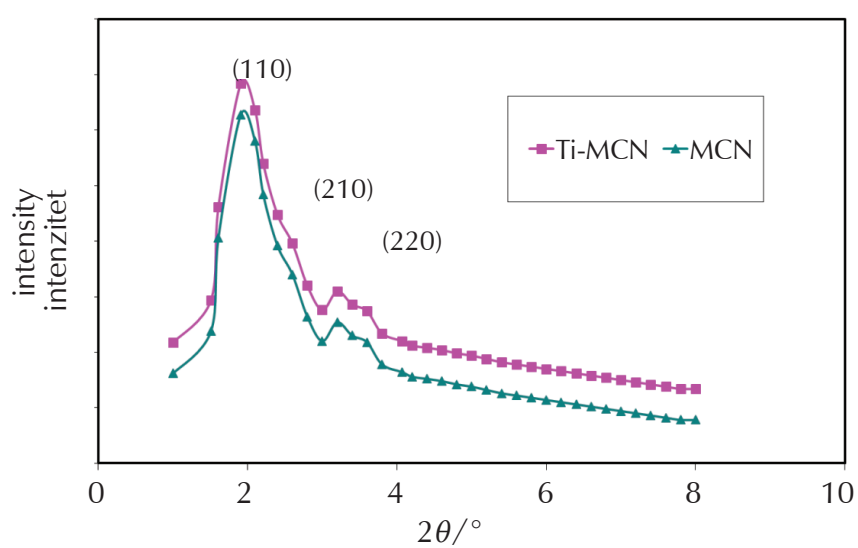

Fig. 2 - XRD pattern of MCN and Ti-MCN

Slika 2 - Rendgenski difraktogrami MCN-a i Ti-MCN-a

The observation data from the original samples of all nanostructured carbons are in good agreement with that previously reported..$^{15}$ The wide-angle XRD patterns of titanium oxide modified mesoporous photocatalyst (Ti-MCN) 
in Fig. 3 as revealed by the peaks at $25.3^{\circ}, 37.7^{\circ}, 48.0^{\circ}$, $53.9^{\circ}, 55.1^{\circ}, 62.7^{\circ}, 68.6^{\circ}, 70.4^{\circ}$ and $75.0^{\circ}$ (JCPDS 00-0040477) $2 \theta$, are characteristic of the existence of crystalline $\mathrm{TiO}_{2}$ anatase phase, but the XRD pattern of mesoporous carbon nitride photocatalyst shows no diffraction peak.

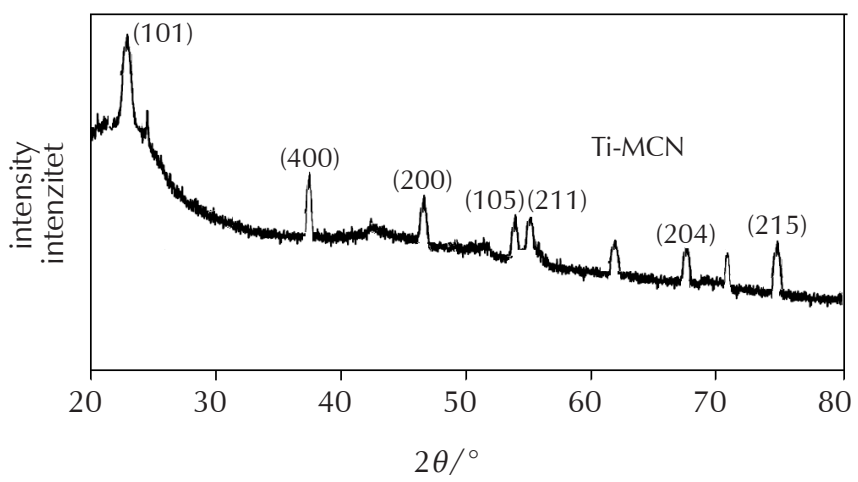

Fig. 3 - Wide angle XRD patterns of Ti-MCN

Slika 3 - Širokokutni rendgenski difraktogrami Ti-MCN-a

\subsection{Photocatalytic activity of Ti-MCN}

Fig. 4 shows the photocatalytic degradation curves of $\mathrm{NB}$ over $\mathrm{TiO}_{2}, \mathrm{MCN}$ and Ti-MCN photocatalysts under UV light irradiation. Experimental outcomes have shown that the photodegradation activity of Ti-MCN catalyst was clearly enhanced in contrast with the $\mathrm{TiO}_{2}$ and $\mathrm{MCN}$. The $\mathrm{TiO}_{2}$ supported mesoporous carbon nitride catalysts were more active than $\mathrm{TiO}_{2}$ (Fig. 4), probably due to the better porosity and structure.

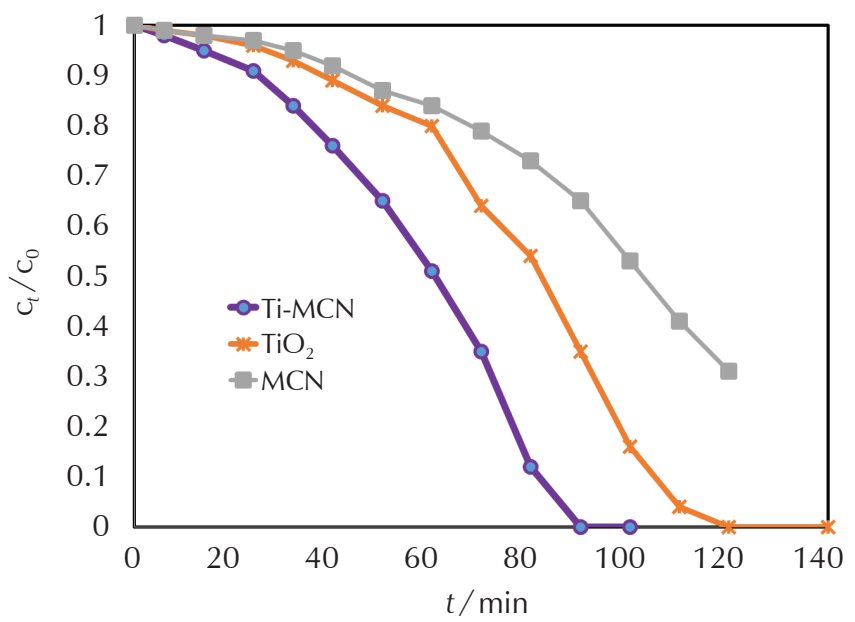

Fig. 4 - Photocatalytic activities of $\mathrm{TiO}_{2}, \mathrm{MCN}$ and Ti-MCN photocatalysts. Catalyst dosage $0.2 \mathrm{gl}^{-1}, \mathrm{NB}$ mass fraction $100 \mathrm{ppm}$, reaction time $3 \mathrm{~h}, \mathrm{pH}=6.5$, temperature $298 \mathrm{~K}$.

Slika 4 - Fotokatalitička aktivnost fotokatalizatora $\mathrm{TiO}_{2}, \mathrm{MCN}$ i Ti-MCN. Koncentracija katalizatora $0,2 \mathrm{~g} \mathrm{I}^{-1}$, maseni udjel NB-a 100 ppm, vrijeme reakcije $3 \mathrm{~h}, \mathrm{pH}=6,5$, temperatura $298 \mathrm{~K}$.
These outcomes propose that the loading of the titanium oxide particles on the surface of the support and the better accessibility of the reactants might be more favourable for the photocatalytic reaction. The mesoporous carbon nitride had a larger specific surface area than $\mathrm{TiO}_{2}$, and $\mathrm{TiO}_{2}$ modified mesoporous carbon nitride due to better porosity and more ordered structure but had low catalytic activity.

The higher photocatalytic activity of mesoporous carbon nitride and titanium oxide modified sample here observed may be attributed to several factors. 1) The increasing adsorption capacity of the photocatalyst; NB molecules would transfer from the solution to the catalysts' surface and be adsorbed with offset face-to-face orientation via $p-p$ conjugation between NB and aromatic regions of the carbonaceous photocatalyst. Therefore, the adsorption of 1,3-dinitrobenzene is increased compared to $\mathrm{TiO}_{2}$. 2) Extending light absorption; the chemical bonds of $\mathrm{Ti}-\mathrm{O}-\mathrm{C}$ and good transparency of photocatalyst made a red shift in the photo responding range, and facilitated a more efficient use of light for the photocatalysis. 3) Overpowering charge recombination; the carbon nitride surface can act as an acceptor of the photo-generated electrons for titanium dioxide particles and confirm a fast charge moving in view of its great conductivity, and therefore, an effective charge separation can be attained. ${ }^{22,23}$ The better charge transportation would provide more photo-induced carriers for the associated photocatalytic reactions, due to a higher photocatalytic activity.

To find the order of the reaction of photochemical degradation of NB by Ti-MCN photocatalyst, pseudo-first-order and pseudo-second-order models were used. For first order reaction, the semi-log of residual NB $\left(\ln [N B]_{t} /[N B]_{i}\right)$ versus reaction time $(t)$ was plotted. Similarly, the $1 /[N B]_{t}$ versus $t$ was plotted for second-order reaction. A comparison of two kinetic models indicates that the first-order kinetics fits better with the data $\left(R^{2}=0.998\right)$ than the second-order kinetics $\left(R^{2}=0.965\right)$. The corresponding rate coefficient $(k)$ for the first-order reaction was found to be $4.64 \cdot 10^{-2} \mathrm{~min}^{-1}$.

The effect of photocatalyst dosage on the photodegradation of NB was examined in UV irradiation by different dosage of Ti-MCN varying from $0.02 \mathrm{gl}^{-1}$ to $0.2 \mathrm{gl}^{-1}$ at a fixed 1,3-dinitrobenzene concentration of $100 \mathrm{ppm}$. The photodegradation rate for photocatalyst is presented in Fig. 5, which shows that initial slopes of the curves rise greatly by increasing catalyst amount, and after that the amount of degradation remained almost constant.

Hence, the maximum photodegradation is shown with $0.15 \mathrm{~g} \mathrm{l}^{-1}$ dose of Ti-MCN. Similar research was carried out by Muruganandham et al. ${ }^{24}$ The NB degradation improved meaningfully by increasing the dosage of photocatalyst. The increase in the amount of catalyst increases the number of active sites of $\mathrm{TiO}_{2}$ that in turn increases the number of $\mathrm{OH}^{*}$ and $\mathrm{O}_{2}{ }^{-}$radicals. The photocatalytic destruction of other organic pollutants has also shown a similar type of dependence on photocatalyst dosage. ${ }^{25,26}$ 


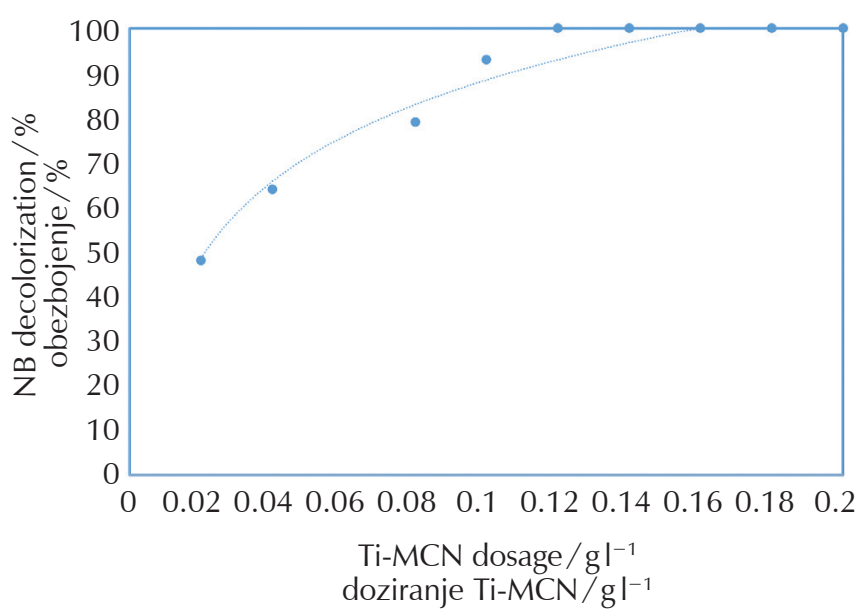

Fig. 5 - Influence of Ti-MCN amount on the degradation of NB. Mass fraction of NB $100 \mathrm{ppm}$, reaction time $3 \mathrm{~h}$, $\mathrm{pH}=6.5$, temperature $298 \mathrm{~K}$.

Slika 5 - Utjecaj količine Ti-MCN-a na razgradnju NB-a. Maseni udjel NB-a 100 ppm, vrijeme reakcije $3 \mathrm{~h}, \mathrm{pH}=6,5$, temperatura $298 \mathrm{~K}$.

\section{Conclusions}

In summary, a highly ordered three-dimensional mesoporous carbon nitride material (MCN) with high surface area and pore volume has been prepared using MCM-48, as a template through a simple polymerization reaction between ethylenediamine and carbon tetrachloride, after that modified with $\mathrm{TiO}_{2}$. The structural order and textural properties of the modified and unmodified mesoporous photocatalysts was studied by XRD and nitrogen adsorption analyses. The photocatalytic activity of the Ti-MCN composite was examined by the degradation of NB in aqueous solutions under UV light irradiation. The photocatalytic degradation of NB fits the pseudo-first-order kinetic model. The $\mathrm{TiO}_{2}$ modified mesoporous carbons prepared in this work are suitable for the NB dye photocatalysts.

\section{ACKNOWLEDGEMENTS}

The authors thank The Research Council at the Azad University for financial support.

\section{List of abbreviations and symbols Popis kratica i simbola}

$\begin{array}{ll}\text { BET } & - \text { Brunauer-Emmett-Teller } \\ \text { BJH } & - \text { Barrett-Joyner-Halenda } \\ \text { CTAB } & \text { - cetyltrimethylammonium bromide } \\ & \text { - cetiltrimetilamonijev bromid } \\ \text { CTC } & - \text { carbon tetrachloride } \\ & - \text { ugljikov tetraklorid } \\ \text { EDA } & \text { - ethylenediamine } \\ & \text { - etilendiamin } \\ \text { MCM-48 } & - \text { mesoporous silica } \\ & - \text { mezoporozni silicijev dioksid }\end{array}$

\begin{tabular}{|c|c|}
\hline $\mathrm{MCN}$ & $\begin{array}{l}\text { - mesoporous carbon nitride } \\
\text { - mezoporozni ugljikov nitrid }\end{array}$ \\
\hline NB & $\begin{array}{l}\text {-1,3-dinitrobenzene } \\
\text { - 1,3-dinitrobenzen }\end{array}$ \\
\hline STP & $\begin{array}{l}\text { - standard temperature and pressure } \\
\text { - standardni tlak i temperatura }\end{array}$ \\
\hline TEOS & $\begin{array}{l}\text { - tetraethyl orthosilicate } \\
\text { - tetraetil-ortosilikat }\end{array}$ \\
\hline Ti-MCN & $\begin{array}{l}\text { - MCN modified by } \mathrm{TiO}_{2} \text { nanoparticles } \\
\text { - MCN modificiran nanočesticama } \mathrm{TiO}_{2}\end{array}$ \\
\hline XRD & $\begin{array}{l}\text { - X-ray diffraction } \\
\text { - rendgenska difrakcija }\end{array}$ \\
\hline$A$ & $\begin{array}{l}\text { - absorbance } \\
\text { - apsorbancija }\end{array}$ \\
\hline$b$ & $\begin{array}{l}\text { - pathlength, } \mathrm{cm} \\
\text { - duljina puta, cm }\end{array}$ \\
\hline C & $\begin{array}{l}\text { - amount concentration, } \mathrm{mol} \mathrm{dm}^{-3} \\
\text { - množinska koncentracija, mol dm } \mathrm{dm}^{-3}\end{array}$ \\
\hline$k$ & $\begin{array}{l}\text { - rate coefficient, } \min ^{-1} \\
\text { - koeficijent brzine, } \min ^{-1}\end{array}$ \\
\hline$t$ & $\begin{array}{l}\text { - time, } \min \\
\text { - vrijeme, } \min \end{array}$ \\
\hline$\varepsilon$ & $\begin{array}{l}\text { - molar absorption coefficient, } \mathrm{dm}^{3} \mathrm{~mol}^{-1} \mathrm{~cm}^{-1} \\
\text { - molarni apsorpcijski koeficijent, } \mathrm{dm}^{3} \mathrm{~mol}^{-1} \mathrm{~cm}^{-1}\end{array}$ \\
\hline$\theta$ & $\begin{array}{l}\text { - diffraction angle, } \\
\text { - difrakcijski kut, }\end{array}$ \\
\hline$\lambda$ & $\begin{array}{l}\text { - wavelength, } \mathrm{nm} \\
\text { - valna duljina, } \mathrm{nm}\end{array}$ \\
\hline
\end{tabular}

\section{References Literatura}

1. I. K. Huh, D. I. Song, Y. W. Jeon, Sorption of phenol and alkylphenols from aqueous solution onto organically modified montmorillonite and applications of dual-mode sorption model, Sep. Sci. Technol. 35 (2) (2000) 243-259, doi: http://dx.doi.org/10.1081/SS-100100154.

2. A. M. Mastral, T. García, R. Murillo, M. S. Callén, M. V. Navarro, J. Galbán, Assessment of phenanthrene removal from hot gas by porous carbons, Energy Fuels 15 (1) (2001) 1-7, doi: http://dx.doi.org/10.1021/ef000116g.

3. N. Irha, E. Teinemaa, Behavior of three- to four-ring PAHs in the presence of oil shale ash and aluminosilicate matter, Polycyclic Aromat. Compd. 22 (3-4) (2002) 663-671, doi: http://dx.doi.org/10.1080/10406630213579.

4. M. Ghiaci, A. Abbaspur, R. Kia, F. Seyedeyn-Azad, Equilibrium isotherm studies for the sorption of benzene, toluene, and phenol onto organo-zeolites and as-synthesized MCM-41, Sep. Purif. Technol. 40 (3) (2004) 217-229, doi: http://dx. doi.org/10.1016/j.seppur.2004.03.001.

5. W. T. Tsai, C. W. Lai, T. Y. Su, Adsorption of bisphenol-A from aqueous solution onto minerals and carbon adsorbents, J. Hazard. Mater. 134 (1-3) (2006) 169-175, doi: http://dx. doi.org/10.1016/j.jhazmat.2005.10.055.

6. A. S. Özcan, A. Özcan, Adsorption of acid dyes from aqueous solutions onto acid-activated bentonite, J. Colloid Interf. Sci. 276 (1) (2004) 39-46, doi: http://dx.doi.org/10.1016/j. jcis.2004.03.043.

7. M. Khalid, G. Joly, A. Renaud, P. Magnoux, Removal of phenol from water by adsorption using zeolites bain, Ind. Eng. Chem. Res. 43 (17) (2004) 5275-5280, doi: http://dx.doi. org/10.1021/ie0400447. 
8. D. Kratochvil, P. Pimentel, B. Volesky, Removal of trivalent and hexavalent chromium by seaweed biosorbent, Environ. Sci. Technol. 32 (1998) 2693-2698, doi: http://dx.doi. org/10.1021/es971073u.

9. P. F. Fu, Y. Luan, X. G. Dai, Preparation of activated carbon fibers supported $\mathrm{TiO}_{2}$ photocatalyst and evaluation of its photocatalytic reactivity. J. Mol. Catal. A: Chem. 221 (2004) 8188, doi: http://dx.doi.org/10.1016/j.molcata.2004.06.018.

10. A. Fujishima, T. N. Rao, D. A. Tryk, Titanium dioxide photocatalysis, J. Photochem. Photobiol. A 1 (2000) 1-21, doi: http://dx.doi.org/10.1016/S1389-5567(00)00002-2.

11. A. L. Linsebigler, G. Lu, J. T. Yates, Photocatalysis on $\mathrm{TiO}_{2}$ surfaces: principles, mechanisms, and selected results, Chem. Rev. 95 (1995) 735-758, doi: http://dx.doi.org/10.1021/ cr00035a013.

12. J. Y. Li, W. H. Ma, C. C. Chen, J. C. Zhao, H. Y. Zhu, X. P. Gao, Photodegradation of dye pollutants on one-dimensional $\mathrm{TiO}_{2}$ nanoparticles under UV and visible irradiation, J. Mol. Catal. A: Chem. 261 (2007) 131-138, doi: http://dx.doi. org/10.1016/j.molcata.2006.08.018.

13. J. J. Liu, X. P. Li, S. L. Zuo, Y. C. Yu, Preparation and photocatalytic activity of silver and $\mathrm{TiO}_{2}$ nanoparticles/montmorillonite composites, Appl. Clay Sci. 37 (2007) 275-280, doi: http:// dx.doi.org/10.1016/j.clay.2007.01.008.

14. D. E. Gu, B. C. Yang, Y. D. Hu, V and $\mathrm{N}$ co-doped nanocrystal anatase $\mathrm{TiO}_{2}$ photocatalysts with enhanced photocatalytic activity under visible light irradiation, Catal. Commun. 9 (2008) 1472-1476, http://dx.doi.org/10.1016/j. catcom.2007.12.014.

15. A. Vinu, K. Ariga, T. Mori, T. Nakanishi, S. Hishita, D. Golberg, Y. Bando, Preparation and characterization of well-ordered hexagonal mesoporous carbon nitride, Adv. Mater. 17 (2005) 1648-1652, doi: http://dx.doi.org/10.1002/ adma.200401643.

16. Y. Shao, L. Wang, J. Zhang, M. Anpo, Novel synthesis of high hydrothermal stability and long-range order MCM-48 with a convenient method, Micropor. Mesopor. Mater. 109 (2005) 314-322, doi: http://dx.doi.org/10.1016/j.micromeso.2005.07.043.
17. U. Ciesla, F. Schüth, Ordered mesoporous materials, Micropor. Mesopor. Mater. 27 (1999) 131-149, doi: http://dx.doi. org/10.1016/S1387-1811(98)00249-2.

18. A. Saito, H. C. Foley, Curvature and parametric sensitivity in models for adsorption in micropores, AIChE J. 37 (1991) 429-436, doi: http://dx.doi.org/10.1002/aic.690370312.

19. Y. Xun, Z. Shu-Ping, X. Wei, C. Hong-You, D. Xiao-Dong, L. Xin-Mei, Y. Z. Feng, Aqueous dye adsorption on ordered mesoporous carbons, J. Coll. Interf. Sci. 310 (2007) 83, doi: http://dx.doi.org/10.1016/j.jcis.2007.01.069.

20. S. Jun, S. H. Joo, R. Ryoo, M. Kruk, M. Jaroniec, Z. Liu, T. Ohsuna, O. Terasaki, Synthesis of new nanoporous carbon with hexagonally ordered mesostructure, J. Am. Chem. Soc. 122 (2000) 10712-10713, doi: http://dx.doi.org/10.1021/ ja002261e.

21. N. Kawasaki, R. Bunei, F. Ogata, S. Tanei, S. Tanada, Water treatment technology using carbonaceous materials produced from vegetable biomass, J. Water Environ. Technol. 4 (2006) 73-82, doi: http://dx.doi.org/10.2965/jwet.2006.73.

22. S. D Miao, Z. M. Liu, B. X. Han, J. L. Zhang, X. Yu, J. M. Du, Z. Y. Sun, Synthesis and characterization of $\mathrm{TiO}_{2}-$ montmorillonite nanocomposites and their application for removal of methylene blue, J. Mater. Chem. 16 (2006) 579-584, doi: http://dx.doi.org/10.1039/b511426h.

23. H. Yoneyama, S. Haga, Photocatalytic activities of microcrystalline titania incorporated in sheet silicates of clay, J. Phys. Chem. 93 (1989) 4833-4837, doi: http://dx.doi. org/10.1021/j100349a031.

24. M. Muruganandham, M. Swaminathan, Photocatalytic decolouration and degradation of reactive orange 4 by $\mathrm{TiO}_{2}-\mathrm{UV}$ process, Dyes Pigm. 76 (2006) 113-117.

25. A. Akyol, H. C. Yatmaz, H. Bayramoglu, Photocatalytic decolorization of remazol red $\mathrm{RR}$ in aqueous $\mathrm{ZnO}$ suspensions, Appl. Catal. B 54 (2004) 19-24, doi: http://dx.doi. org/10.1016/j.apcatb.2004.05.021.

26. A. K. Jain, V. K. Gupta, A. Bhatnagar, S. Jain, A. Suhas, Comparative assessment of adsorbents prepared from industrial wastes for the removal of cationic dye, J. Indian Chem. Soc. 80 (2003) 267-270.

\section{SAŽETAK}

\section{Utjecaj modifikacije mezoporoznog ugljikova nitrida nanočesticama titanijeva oksida na fotokatalitičku razgradnju 1,3-dinitrobenzena \\ Seyyed Ershad Moradi}

Reakcijom etilendiamina i ugljikova tetraklorida u mezoporoznom silicijevu dioksidu sintetiziran je uniformno mezoporozni ugljikov nitrid velike specifične površine i volumena pora. Zatim je modificiran nanočesticam $\mathrm{TiO}_{2}(\mathrm{Ti}-\mathrm{MCN})$. Struktura i tekstura nanoporoznog materijala proučavani su rendgenskom difrakcijom, elementnom analizom te adsorpcijom i desorpcijom dušika.

U šaržnoj fotorazgradnji 1,3-dinitrobenzena katalizator Ti-MCN aktivniji je od slobodnih nanočestica $\mathrm{TiO}_{2}$.

\section{Ključne riječi \\ 1,3-dinitrobenzen, mezoporozni ugljikov nitrid, razgradnja, titanijev oksid}

Young Researchers and Elite Club Islamic Azad University-Sari Branch 39715-194, Iran
Izvorni znanstveni rad Prispjelo 5. kolovoza 2014. Prihvaćeno 15. studenoga 2014. 